\title{
Improve The Quality of Parenting for Parents who have Early Childhood with Visual Impairment Through Parents Attachment
}

\author{
Ofi Riega, Sunardi, Hidayat \\ Special Education Study Program \\ Universitas Pendidikan Indonesia \\ Bandung, Indonesia \\ ofiriega@student.upi.edu,nardilembang@gmail.com, hidayatday999@yahoo.com
}

\begin{abstract}
Parents Attachment is a form of parenting that is useful for building attachment between parents and children. This study aims to improve the quality of parenting for parents who have children with visual impairment through parents attachment. It employed a descriptive with qualitative approach in expressing objective description of a situation. The subjects of this study were parents who were overprotective in parenting 6year-old children with $d$ visual impairments. The data was collected by observation and interview. Data analyzing was conducted by a triangulation technique. The results of the study showed that parents can apply the principle of parent attachment in daily parenting activities.
\end{abstract}

Keywords-parenting, parents, visual impairment, parents attachment.

\section{INTRODUCTION}

Early childhood is an important stage in children life as they start becoming very critical. These early years influence how the relationship with the family and the wider environment. Therefore, parenting is very important. Children with visual impairment are often regarded as individuals who are not independent. Parents often indulge and help their children's work because they have visual impairments. While children need to develop according to their age. Early childhood requires a sense of security and comfort to be able to engage in activities that are developed through feelings of language, learning about the environment and making choices [1]. To build security and comfort for children, parenting with behavior that always limits children's movement must be corrected through the principles that are in parents attachment. Attachment is a close emotional bond between two people [2]. Parents attachment is a bond between children and parents. Parents are the main context of attachment patterns and emotional adjustment strategies that determine children's relationships with others and socialize [3]. The expected result of parents attachment is securely attached babies. Children who have safe attachments will easily socialize with new and larger environments.

\section{METHOD}

This study used a descriptive method with qualitative approach. Qualitative research is a human instrument. It means that researchers were informants as data sources, collecting and analyzing data, interpreting and drawing conclusions from the findings [4]. Qualitative data of this study was collected from various general questions that allow participants to respond, and the data collected were in the form of words or pictures [5]. The main reason for using a qualitative approach to early childhood education is to express the ineffectiveness of traditional scientific methods and their limited reach [6]. The subject of this study were parents who were overprotective in parenting for children aged 6 years who had visual impairments. These children show lack of motivation and enthusiasm in doing every activity at school and at home because their parents do not give opportunity to doing something. Parents say sorry if children have to do their own activities. The data was collected by observation and interview, using observation sheet and interview list. The data then analyzed by using triangulation technique.

\section{RESUlT AND DISCUSSION}

Parenting based parent attachments are formed from several principles, namely, trust, motivation, opportunity, support, and reward. The establishment of a program in the form of child assistance program carried out by parents who are divided into several activities. Activities carried out such as cycling, throwing catches and all activities involving movement. In each activity, parents were required to believe that children can carry out these activities; then, they gave motivation to children with sentences that have been agreed upon beforehand. During the activities, parents must focus on the child without being allowed to do other activities such as playing gadgets. They were also not allowed to help children but may encourage children, should not be high-pitched and loud when giving directions. After the activity was completed, parents were required to praise or caress the child as a reward. Everything conducted by parents would be checked so that later parents would be familiar with the principle even with different types of activities. Below is the program 
implementation procedures applied in this study. These activities carried out for two months.

TABLE I. DESCRIPTION OF PROGRAM IMPLEMENTATION PROCEDURES

\begin{tabular}{|c|c|c|c|}
\hline Location & Purpose & Activities & Period \\
\hline \multirow[t]{6}{*}{$\begin{array}{l}\text { Subject } \\
\text { house }\end{array}$} & $\begin{array}{l}\text { improve } \\
\text { the } \\
\text { quality of } \\
\text { parenting }\end{array}$ & $\begin{array}{l}\text { Researchers educate parents } \\
\text { about the importance of giving } \\
\text { children the opportunity to do } \\
\text { each activity independently and } \\
\text { pleasantly. }\end{array}$ & \multirow{4}{*}{1 day } \\
\hline & & $\begin{array}{l}\text { The researchers provide an } \\
\text { explanation of the activity } \\
\text { procedure according to the } \\
\text { principle of parent attachment. }\end{array}$ & \\
\hline & & $\begin{array}{l}\text { Researchers and parents agree } \\
\text { on the form of motivation and } \\
\text { rewards that children will } \\
\text { receive according to the results } \\
\text { shown by the child. }\end{array}$ & \\
\hline & & $\begin{array}{l}\text { Parents narrate every activity } \\
\text { carried out and the environment } \\
\text { around each activity. }\end{array}$ & \\
\hline & & $\begin{array}{l}\text { During activities, parents are } \\
\text { required to trust the child and } \\
\text { accompany the child by } \\
\text { motivating. }\end{array}$ & \multirow[t]{2}{*}{30 days } \\
\hline & & $\begin{array}{l}\text { After the activity is completed, } \\
\text { parents give rewards to the child } \\
\text { in the form of praise or touch. }\end{array}$ & \\
\hline
\end{tabular}

During the activities, the children look confident and happy. Confidence is capital towards a more complete activity. Children felt happy because the freedom given was accompanied by a sense of comfort and safety. Children would easily adapt to the larger environment of the community. Every activity that is successfully carried out by the children proves to the parents that the vision barrier that the children have is not a barrier for the child to be independent. Excessive anxiety of parents on children's abilities can also be minimized by applying parenting with the principle of parent attachment.

The principles of parent attachment that are applied in parenting can be a habit in the family so that parents and children feel comfortable and safe when doing activities. Fear of parents regarding the limitations of children so that children can not do activities independently can be minimized. Parental trust can produce confidence in children, so that children can actively move without feeling restrained. All children need the feelings of love and peace, so they can grow up healthy, happy and able to play actively in the community and society [7].
Parents have a capital of love for children but sometimes there is a wrong way to use it. Therefore, it is important to establish good attachments. In establishing a secure attachment, it requires sufficient effort, but the results are very good for children and parents [8]. During and after the implementation of the program, the children look happier and often laughs, parents also have the willingness to accompany children to do activities (not to replace children doing activities). Attachment is the most popular theory that empirically relates to parenting which involves the relationship between children and caregivers aimed at making children safe and protected [9]. There are three important components in a learning environment is the structure of opportunity, support, and reward [10]. Attachments are considered to improve the relationship between parents and children by applying the principles in parenting.

\section{CONCLUSION}

Based on the analysis, it can be concluded that 1) the principle of parents attachment can improve the quality of parenting 2) parenting attachment-based parenting can lead to comfort and feelings of happiness for children 3) the program is based on family assessment.

\section{REFERENCES}

[1] United States. Department of Education, Parent Power Build the Bridge to Success. Washington, Dc.: Department of Education, 2010.

[2] J. W. Santrock, Perkembangan Anak Jilid Dua, 11th ed. Jakarta: Erlangga, 2007.

[3] N. E. Doinita and N. D. Maria, "Attachment and Parenting Styles. Procedia - Social and Behavioral Sciences," Journal of attachment theory, vol. 203, pp. 199-204, 2015.

[4] S. Sugiyono, Statistika untuk Penelitian. Bandung: Alfabeta, 2010.

[5] J. Creswell, Riset Pendidikan Perencanaan, Pelaksanaan dan Evaluasi Riset Kuantitatif dan Kualitatif. Yogyakarta: Pustaka Pelajar, 2015.

[6] M. D. Roberts, "The Role of Qualitative Methods in Early Childhood Education: A Review of J. Amos Hatch's Early Childhood Qualitative Research," The Weekly Qualitative Report, vol. 2, no. 15, pp. 90-93, 2009.

[7] UNESCO, Parenting Education Guidebook. Thailand: Asia and Pacific Regional Bureau for Education, 2011.

[8] J. Saisan, Parenting and Attachment Advice for Bonding Your Baby. Farmington: Franklin Country Children's Task Force, 2008.

[9] D. Benoit, "Infant-parent attachment: Definition, Types, Antecendents, Measurement, Outcomes," Pediatry Child Health, vol. 9, no. 8, 2004.

[10] D. Tarsidi, "Intervensi bimbingan dan konseling untuk Membantu Perkembangan Kompetensi Sosial Anak Tunanetra,” 2008. 